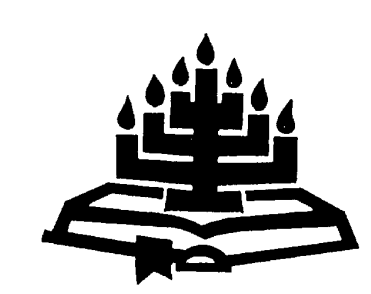

\title{
Calvijn en de biecht ${ }^{1}$
}

\author{
H.A. Speelman ${ }^{2}$
}

Pacific Islands Bible College

GUAM

VSA

E-pos: pibcoll@netpci.com

\section{Abstract \\ Calvin and the act of confession}

In 1540 Calvin declared that no member of the congregation would be allowed to take part in the ceremony of Holy Communion unless this ritual had been preceded by the act of confession. With this declaration Calvin, however, aimed to urge and encourage his fellow-believers to scrutinize their religious lifestyle on a disciplined and regular basis. Calvin regarded confession as a pastoral aid and an embodiment of compassion and admonition. Simultaneously it could also serve as a measure of social control.

In this article the author consecutively outlines the practice of confession in medieval times and the way in which confession was implemented as a disciplinary device. In conclusion it is stated that, in line with the view point of the Reformation, Calvin allowed the members of the congregation the freedom to confess to fellow members. He, however, also stressed the importance and obligation to allow members of the consistory - and especially the minister - to investigate the condition of one's religious lifestyle. Self-investigation should be coupled with regular house visitation in order to ascertain the quality of believers' religious lives.

\section{De biecht als gesprek}

Op Pasen 1540 deelde de 30-jarige predikant van de kleine, Franse vluchtelingengemeente in Straatsburg van de kansel mee dat voortaan niemand meer tot

1 Redaksioneel versorg deur In die Skriflig.

2 Dr. Speelman was tot 1995 predikant van die Gereformeerde Kerk in Vorden. Sedert 1994 was hy dosent in Kerkgeskiedenis by die Reformatorische Hogeschool in Zwolle. Hy het ook Apologetiek gedoseer by die Hindustan Bybelinstituut in Madras, Indië. Sedert 1999 is hy dosent by die Pacific Islands Bible College in Guam. 
het avondmaal zou worden toegelaten die zich niet tevoren in een biechtgesprek met de eigen predikant of zijn vervanger aan een onderzoek liet onderwerpen.

De directe aanleiding tot het invoeren van het verplichte biechtgesprek in het voorjaar van 1540 was een kwestie met een aantal Franse studenten.

Velen gingen overmoedig aan het avondmaal. Toen ik op Paaszondag afkondigde, dat wij aanstaande zondag het avondmaal hopen te vieren, legde ik tegelijk uit, dat niemand door mij toegelaten zou worden die zich niet aan een contrôle-onderzoek zou onderwerpen. De grote moeilijkheid zal zijn de dwaze eerzucht te corrigeren, waarvan sommige Fransen zo bezeten zijn, dat men deze nauwelijks uit hun ziel kan rukken (Herminjard, 6 no. 857, 22; Calvijn aan Farel - 29 Maart 1540).

Enigen van Calvijns vrienden toonden zich hierover verontrust, bang voor een terugkeer naar de praktijk van de paapse biecht. Calvijn ging er echter vanuit dat de kerk het volste recht had een onderzoek in te stellen naar leer en leven van de gelovigen. Tegenover zijn vriend, Farel, verdedigde hij zich enkele weken later krachtig: "Reeds vaak heb ik u betuigd, dat het mij voor de kerken niet nuttig toescheen de biecht (confessio) af te schaffen zonder die te vervangen door wat ik onlangs heb ingesteld." Hermj. 6, no. 863, 223-224; Calvijn aan Farel 13 mei 1540 .

Hoewel hij zich in zijn Institutie duidelijk had uitgesproken tegen de biechtplicht in de gevestigde kerk, verdedigde hij in Straatsburg te vuur en te zwaard een vorm van biechtplicht, waarbij hij dacht aan een pastoraal gesprek voorafgaand aan het avondmaal.

Dat over ons avondmaalsonderzoek, waarover ik je schreef (ruim een maand eerder op 29 maart 1540), onze goede broeders hun bedenkingen hebben, verwondert me niets. Want het is niet nieuw voor mij dat er goede zielen zijn die vrees hebben terug te vallen in bijgelovigheid of iets dat een zekere verwantschap of gelijkheid heeft met de pauselijke verzinsels (Hermj. 6, no. 863, 223).

Ontgoocheld door ervaringen in Genève (van najaar 1536 tot voorjaar Pasen 1538), broedde Calvijn in Straatsburg op een nieuwe vorm van avondmaalstucht. Het is feitelijk een vorm van de oorbiecht, waarbij Calvijn er van uit ging dat de kerk het volste recht had leer en leven van de gelovigen te onderzoeken.

Want hoe schaamteloos zou het zijn de kerk niet waardig te achten, uw geloof goed te keuren, met wie u toch de avondmaalsgemeenschap begeert? En wat een droevige toestand zou het zijn in de kerk, wanneer zij tot de gemeenschap van een zo heilig sacrament mensen zou moeten opnemen die zij helemaal niet kent of die haar bijzonder verdacht voorkomen! (Hermj. 6, no. 863,224$)$. 
Een voorval in Straatsburg in april 1539 illustreert dat Calvijn - evenals in de jaren hiervoor in Genève - in Straatsburg worstelde met de toelating tot het avondmaal, sinds het avondmaal in de Franse vluchtelingenkerk aldaar op 3 november 1538 voor het eerst was gevierd. Er was ter plaatse een verziekende figuur (pestis illa), die zich een maand niet had vertoond in een kerkdienst. Hij leidde een zondig en ergernis wekkend leven van dobbelen en dronkenschap, "als op een openbare markt". Daarbij liep het gerucht, dat hij zich schuldig zou maken aan bordeelbezoek. Toch zou hij deelgenomen hebben "aan het zeer heilige avondmaal (ad sacrosanctum illud mysterium), als ik hem niet de weg versperd had". Calvijn had hem eerder laten weten dat hij zich eerst tegenover hem van zijn schuld moest zuiveren en uitdrukkelijk beterschap beloven. De man liet nu via een tussenpersoon schertsend weten "dat hij de biecht overliet aan de pausgezinden". Calvijn antwoordde, dat er ook zoiets was als "een soort christelijke biecht (genus confessionis Christianae)" (Hermj. 5, no. 784, 291; Calvijn aan Farel; eind april 1539). Uiteindelijk vroeg de man toch in genade te mogen worden aangenomen. Calvijn hoopte, dat hij "door ernstige mildheid de hardnekkigheid van de zondaar kon breken" en hij was blij dat het nog veertien dagen duurde voor het avondmaal gevierd zou worden, zodat hij nog kon constateren of de man werkelijk berouw had (Hermj. 5, no. 784, 294).

Volgens Calvijn heeft de kerk het recht en de plicht het geloof van mensen, die de eenheid in Christus met haar aan het avondmaal willen beleven, te beproeven. Zij kan toch niet zomaar iedereen aan het avondmaal toelaten. Een individueel onderzoek moet waardigen en onwaardigen scheiden. De nieuwe regel is dat, wanneer de dag van het avondmaal aanstaande is, Calvijn afkondigt dat degenen die begeren te communiceren zich vooraf bij hem moeten vervoegen,

... opdat zij die nog onkundig zijn en ongeoefend in de religie, beter worden gevormd; voorts opdat zij die behoefte hebben aan een bijzondere vermaning, deze te horen krijgen; tenslotte opdat indien er mochten zijn die soms door een of andere gewetensnood gekweld worden, zij vertroosting ontvangen mogen. En omdat er gevaar bestaat, dat de gemeente, die niet genoeg weet te onderscheiden tussen het juk van Christus en de heerschappij van de antichrist, gaat wanen dat haar een nieuwe slavernij wordt opgelegd, bestrijd ik een dergelijke twijfel (Hermj. 6, no. 863, 224).

De biecht voorafgaand aan het avondmaal was voor Calvijn niet een nieuw juk, maar een pastoraal middel van vertroosting en vermaning, en tegelijk een vorm van sociale controle, ter bescherming van de kerkelijke eenheid. Een half jaar na de invoering van de nieuwe biechtregeling in de kerk van Calvijn, ontstaat er in de gemeente opschudding over een huwelijk van een 70 -jarige weduwe met een veel jongere man. Vanuit Worms schreef Calvijn aan de hulpprediker Nicolas Parent: "Wij moeten dus maar genoegen nemen met uw vriendelijke vermaning en niet verder op het recht van onze kerk staan. Maar dit is wel een voorbeeld dat ons waarschuwt in de toekomst van de orde niet af te wijken" (Hermj. 6, no. 
925:399-400; Calvijn aan Parent - 14 dec. 1540). Calvijn vernam ook dat het avondmaal niet tijdig genoeg kon worden aangekondigd. Daarop werd op advies van Calvijn de viering uitgesteld. De afspraak dat ieder afzonderlijk (solitam) het gewetensonderzoek, "l'examen de conscience des communiants", moest ondergaan, zou nauwkeurig in acht genomen moeten worden (Hermj. 6, no. 917, 376; Calvijn aan Parent - 26 nov. 1540; Hermj. 6, no. 857, 200; Calvijn aan Farel - 29 maart 1540). Wanneer de viering wel zou zijn doorgegaan, "kon dit niet gebeuren dan met verwaarlozing van de orde die ik niet zonder reden nauwkeurig wil zien nakomen", schrijft hij op 14 december 1540 aan Parent (Hermj. 6, no. 925, 397). Calvijn is voor een strenge biechtplicht die de oude vervangt, want ...

hoe moet de pastor, aan wie de uitdeling van zulke genadegeschenken toevertrouwd is, zich houden aan de eis van de wet het heilige niet te verkwanselen aan honden of zwijnen noch te verkwisten zonder enig onderscheid tussen waardige en onwaardige? Hoe moet hij dit ambt bekleden wanneer hij niet een bepaald middel heeft om de waardigen van de onwaardigen te scheiden? (Hermj. 6, no. 863, 224).

\section{De middeleeuwse biecht}

Het grote Lateraans concilie van 1215 legde een relatie tussen de eucharistie en de biecht. Iedere leek werd in canon 21 op zijn plicht gewezen om zich jaarlijks bij zijn priester te melden. Twee dingen werden van toen af aan van elke christenmens verwacht. Hij moest tenminste eenmaal per jaar al zijn zonden belijden bij zijn eigen priester (in de tijd voor Pasen), en met Pasen eerbiedig het sacrament van de eucharistie ontvangen. (Deze koppeling van communie en biecht bewerkte dat de biecht steeds meer als sacrament zou worden ervaren.)

Laat iedere gelovige van beide seksen, nadat hij tot de jaren van onderscheid is gekomen, individueel (solus) al zijn zonden tenminste eenmaal in het jaar trouw belijden voor zijn eigen priester, en laat hij naar vermogen ernaar streven de opgelegde boete te voldoen, eerbiedig tenminste met Pasen het sacrament van de eucharistie ontvangend, tenzij eventueel naar de raad van de eigen priester hij, vanwege een verstandige reden, tijdelijk gemeend heeft zich van het gebruik hiervan te moeten onthouden (Tanner, 1990:245).

In de literatuur wordt dit besluit om de biecht voor iedere leek verplicht te maken, over het algemeen gezien als een nieuwe fase in de geschiedenis van de biecht. De biecht werd vooral een kerkrechtelijk middel om een greep te krijgen op het denken en het doen en laten van de inwoners van het christelijk westen. Lea (1903:230) noemde dit besluit "perhaps the most important legislative act in the history of the Church". Dietterle (1903:374) gaat er van uit dat na canon 21 "die Beichte nicht mehr ein religiöser, sondern ein rein juristischer Akt" 
geworden was. Anderen, zoals Boyle (1974:126-130) en Ohst (1995), hebben geprobeerd deze visie te weerleggen, maar zonder succes.

Tentler (1977:13) geeft een duidelijk omschrijving van de betekenis van de biecht in de late middeleeuwen.

The first function of ecclesiastical penance ... is discipline, or social control. The penitent was accepted by society and in turn was expected to accept and conform to society's rules. The second function is directed more to the individual: it is the cure of a guilty conscience (Tentler, 1977:13).

De eerste functie van de biecht omschrijft hij als kerkelijke tucht of sociale controle en associeert hij positief met het begeleiden, steunen, helpen, raadgeven en opvoeden van mensen. De sociaal-maatschappelijke en opvoedkundige betekenis van de biecht nam in de late middeleeuwen gestaag toe, waarbij een boetestraf gezien werd als een pastoraal-medische ingreep.

Zo vergelijkt het invloedrijke concilie van 1215 de priester met een geneesheer, die een juiste diagnose moet stellen. De priester moet voorzichtig en nauwkeurig te werk gaan, zoals een arts, die een juiste diagnose van het leven van de patiënt moet stellen. In deze vertrouwde beeldspraak is de biechteling de patiënt, die geen informatie over zijn klachten en kwalen mag achterhouden (Tanner, 1990:245). ${ }^{3}$

Laat de priester discreet en voorzichtig zijn, opdat hij op de wijze van een ervarene 'wijn en olie moge gieten' (Luk. 10:34) in de wonden van de gewonde, nauwgezet informerend naar de omstandigheden van de zondaar en de zonde, waardoor hij tot een wijs inzicht kan komen, welk advies hij hem moet geven, en welk geneesmiddel hij moet toepassen ... om de zieke te genezen (Tanner, 1990:245). ${ }^{4}$

De biechtvader als zielenarts is een geliefd beeld (vgl. Harnack, 1892:37-137; McNeill, 1932:14-26; McNeill, 1951:157). De beroemde hoogleraar en kanselier van de universiteit van Parijs, Jean Gerson, schreef twee eeuwen later in een verhandeling over de kunst van het biecht horen over de biechtvader als over "een bekwame arts van geestelijke ziekten" (Gerson in Tentler, 1977:99-100).

Calvijn omschreef de boete (penitence) - Chrysostomus citerend - als "een medicijn, die de zonde uitblust, een gave uit de hemel geschonken, een bewonderenswaardige deugd, een genade, die de kracht van de wetten overwint" (OS 4; Inst. 3.4.1:85). Elders noemde hij de kerkelijke tucht "een helende straf"

3 Canon 22 stelt dat bij ziekte eerste de "zielenarts" geroepen moet worden.

4 "Genezen" (sanandum); een ander handschrift spreekt over "redden" (salvandum) - Tanner (1990:245); Denziger (1937:21-23). 
en "een medicijn, om de zondaren terug te brengen tot onze Heer" (OS 5; Inst. 4.1.16:20).

Blijvend bij deze beeldspraak wordt de zondaar gezien als een zieke, die hulp nodig heeft. Bij ernstige besmettingsgevaar zal de zieke in quarantaine moeten leven. Pas na genezen verklaard te zijn, kan hij terugkeren in de samenleving. Het kanonieke recht geeft dit duidelijk aan. Het gaat er in de boete volgens dat recht vooral om de zondaar te verzoenen met God en de gemeenschap, waarin hij leeft. "Der Busse ist als des Mittels der Aussöhnung mit Gott und mit der kirchlichen und bürgerlichen Gemeinschaft", concludeert Schmitz (1985:89). Wanneer iemand door bijvoorbeeld een echtbreuk of moord een onvergeeflijke zonde begaat tegen de kerkelijke gemeenschap, moest dit worden hersteld. In de middeleeuwse kerk functioneerden de bisschop en zijn assistenten in dit opzicht als rechters en als verzoenende bemiddelaars (Strijards \& Speelman, 1998) en in de gevestigde kerk in Genève ten tijde van Calvijn kwamen daar met hetzelfde doel de predikant en het raadslid-ouderling als zijn assistent voor in de plaats.

\section{De biecht als disciplinair wapen}

Het eerder genoemde 4e Lateraans concilie bewerkte een enorme toename van priesters. Het was hun taak om boetepreken te houden en de biecht af te nemen.

Wij besluiten dat er in zowel kathedralen als in gewone kerken geschikte mannen moeten worden aangesteld, die de bisschoppen zullen kunnen gebruiken als assistenten en medewerkers, niet alleen in het ambt van prediking, maar ook bij het horen van de biecht en het opleggen van boete en in andere zaken die vereist zijn voor het heil van de zielen 5 (Tanner, 1990:240).

De assistenten van de predikanten, die Calvijn in 1541 naar voren schoof als toezichthouders op het gedrag van de mensen in de kerk, luisterden naar de titel ouderling, opzichter, gecommitteerde of gedeputeerde van de overheid in godsdienstige zaken, en bewaker van de gemeente. Zij kregen geen kerkelijke inzegening, maar maakten samen met de predikanten wel deel uit van het consistorie, een orgaan dat toezicht moest houden op leer en leven van de inwoners in de gereformeerde samenleving (vgl. Speelman, 1997:180-181). Het was de taak van ouderlingen "toe te zien op het leven van ieder afzonderlijk en hen vriendelijk te vermanen, van wie ze zien, dat ze een misstap begaan of een losbandig leven leiden", om alles in de gaten te houden (davoir loeil par tout), samen met de predikanten iedereen te bezoeken en "afzonderlijk te onderzoeken (examiner chacun)" (OS 2:339, 357).

Canon 10 van het $4 \mathrm{e}$ Lateraans concilie. 
De systematische aanpak van aanstootgevend en zondig gedrag, drie eeuwen eerder, onder leiding van Innocentius III en nu bij de hervormingen onder leiding van Calvijn, hadden beide tot doel het levensgedrag van geestelijken en leken te bewaken en te verbeteren (vgl. Speelman, 1997:180-181). Met het oog op dit streven naar meer vroomheid, deze 'Pursuit of Holiness', ontwikkelde Calvijn in Genève eind 1541 een eigen biecht- en boetesysteem. Mensen moeten eerst vriendelijk onder vier ogen worden vermaand ${ }^{6}$ (vgl. Niesel, 1938:61-62). Bij koppig gedrag echter "moet hij ernstig vermaand worden, totdat het consistorie van oordeel is (iudicet consistorium), dat meer strengheid nodig is". Mensen die de kerkdiensten niet bezoeken, bijvoorbeeld moeten door de wijkagent "voor het consistorie (ad consistorium) geroepen worden en vermaand worden. Wie zich bereid om te luisteren en inschikkelijk betoont, moet vriendelijk naar huis gezonden worden" (Artikelen 154 en 155; Niesel, 1938).

Een veel gebruikt middel tot het verbeteren van het gedrag van de zondaar is het brengen van de kwestie in het consistorie.

Maar als er een ernstiger vergrijp is, dat een strengere straf verdient dan om met woorden te worden bestraft, zullen hiervan de rechters van het consistorie (consistorii iudices) kennis nemen, zodat hij, die zo diepgevallen is, geweerd wordt van de maaltijd van de Heer voor een bepaalde korte tijd ... Wie echter tot ergernis van de kerk zullen doorgaan, moeten als verachters van God geweerd worden van het heilig avondmaal (Artikelen 159 en 158; Niesel, 1938).

Een ernstige straf is het tijdelijk ontzeggen van "de toegang tot het avondmaal". Zo moeten mensen, die "hardnekkig op het slechte pad voortgaan, nadat zij tot driemaal vermaand zijn, geweerd worden van het gebruik van het avondmaal". "Als iemand zich halsstarrig (in het Frans: of opstandig), met minachting voor het oordeel van het consistorie (consistorii iudicio), aan de heilige tafel voegt, moet hij door de dienaar verdreven worden." Als het consistorie besloot tot excommunicatie, moest dat gemeld worden aan de magistraat (Artikelen 154, 155 en 164), "comme à noz superieurs" (Kingdon, 1962:2, 51). "Zo vaak als er gevallen ter sprake gebracht zijn bij het consistorie (ad consistorium), waarvan de kennisname een civiele straf of correctie verlangt, laten dan de partijen naar de stadsraad gezonden worden, opdat die een burgerlijk oordeel naar zijn goedvinden velt (Artikel 165)." Het brengen van de zaak voor de stadsraad betekende voor de zondaar een grotere publieke bekendheid van dat waar hij van beschuldigd werd en soms een extra strafprocedure.

6 De nummering van de artikelen is van W. Niesel. Artikel $154 \mathrm{t} / \mathrm{m} 165$ is te vinden in Niesel $(1938: 61-62)=$ CO 10a (1541),29-30 = CO 10a (1561),117-119 = OS 2,358-362 = CS (E. Busch, P. Opitz e.a., 1996 2,268-272). De in deze aantekening genoemde artikelen zijn door Calvijn in november 1553 in het Latijn vertaald, als "enkele zeer belangrijke hoofdstukken" over de kerkelijke tucht. CO 14, no. 1859, 678-680. 
Verschillende burgers in Genève drongen aan op meer helderheid over het onderscheid tussen het burgerlijk recht, "de tijdelijke rechtspraak (la iuridiction temporelle)", en "de kerkelijke tucht van de kerkeraad (la police ecclesiastique tochant le Consistoire) (CO 27, 726-727) ${ }^{7}$. De kerkelijke rechtspraak van het consistorie had immers te maken met iemands geestelijke welzijn (la spirituelle) $(\mathrm{CO} 21,727)^{\mathbf{8}}$. Het consistorie heeft tot taak om schandalen te verminderen en "alle (tous!) christenen te brengen tot de gehoorzaamheid aan en tot de ware dienst van God", zo verklaart Calvijn voor de raad $(052,362)$.

Tussen de verschillende stadstaten en gereformeerde reformatoren bestond verschil van mening over het specifiek kerkelijke karakter van opzicht en tucht. Zo was Bullinger een uitgesproken tegenstander van avondmaalstucht. Hij vond het voldoende dat aanstootgevende misdaden gestraft werden door de christelijke overheid. De kerkelijke tucht in de vroege kerk is zijns inziens een tijdelijke straf die iemand ontvangt "opdat zijn instelling zal verbeteren". Aan Datheen verklaarde hij dat wat hem betreft, in Zürich de kerkelijke tucht niet op eenzelfde rigoureuze wijze als in Genève geregeld behoefde te worden. ${ }^{9}$

Calvijn dacht hier anders over. Aan de predikanten van Zürich verklaarde hij op 26 november 1553 :

Over de excommunicatie zijn de meningen tegenwoordig verdeeld. Ik weet dat er vrome en geleerde mannen zijn, voor wie de kerkelijke tucht onder een christelijke overheid niet noodzakelijk schijnt te zijn. ... Voor mij is de leer van Christus hierover volkomen duidelijk (CO 14, no. 1857, 674).

"Wij beweren dat de gehele zaak duidelijk uiteengezet is" in de aangehaalde kerkorde artikelen, schrijft hij eind november naar Zürich (CO 14 no. 1859m, 680-681). Het verschil in visie tussen Bullinger en Calvijn op disciplinaire maatregelen in de gereformeerde kerk is vooral de avondmaalstucht en de rigoureuze aanpak.

Luther had op 10 december 1520 de middeleeuwse biechtpraktijk demonstratief afgezworen, onder andere door het beroemde biechtboek, de Summa Angelica de casibus conscientiae, van de Italiaanse vicarus-generaal van de minderbroedersfranciskanen Angiolo da Chivasso (Angelus de Clavassio; gestorven 1495) te verbranden, gelijk met de Codex van het kanonieke recht (Codex Iuris Canonici). Hij koppelde de biecht los van de kerkelijke boete en tucht.

7 CO 10a, 120 (Registres du Conseil; dinsdag 30 jan. 1560).

8 CO 10a, 120-121 (Registres du Conseil, donderdag 1 febr. 1560).

9 Bullinger aan Datheen (1 juni 1570). In: Th. Erastus, Explicatio (1589), no. 5, 355-367, 358-359 en 365. De situatie in Bern is beschreven in Speelman (1994:hfst.1). 
Calvijn bracht daarentegen de kerkelijke tucht en boete opnieuw terug in het centrum van het kerkelijk leven door de volle aandacht te geven aan de heiliging, de Pursuit of holiness van samenleving en individu. Hij heeft kritiek op de eenzijdige manier waarop in de gevestigde kerk van zijn dagen de biecht gestalte had gekregen. Dit komt volgens hem onder meer tot uiting in de "immens dikke biechtboeken". Deze wettische aanpak "dient voor een deel tot temming van het vlees en voor een deel tot kastijding en bestraffing van de zonden" (OS 4; Inst. 3.4.1; 1559, 85). Er wordt door de gevestigde geestelijkheid veel gezegd en geschreven over "de verbrijzeling (contritio) en verslagenheid (attritio) van de harten", maar men gaat volgens Calvijn voorbij aan "de vernieuwing van het gemoed", die de ware verbetering van het leven voortbrengt (OS 4; Inst. 3.4.1; 1559, 86).

Calvijn onderscheidt bij de boetepraktijk tussen de boete als genadebelofte aan de gelovigen en de boete als disciplinaire maatregel van de kerk ter verbetering van het gedrag van de mensen.

Want de absolutie die het geloof dient, is niets anders dan een getuigenis genomen uit de onverdiende beloften van het evangelie (om de zondaren te verkondigen dat God aan hen barmhartigheid bewijst). De absolutie die uitgevoerd wordt door de tucht van de kerk, heeft niets te maken met de verborgen zonden, maar strekt tot voorbeeld, met het oog op de publieke ergernis om deze uit de kerk te verwijderen (05 4; Inst. 3.4.23; 1559, 112). ${ }^{10}$

De christelijke boete heeft voor hem te maken met zowel het evangelie als de kerk. Het heeft een innerlijke èn een uiterlijke kant. Aan beide heeft Calvijn iets proberen te doen. Het eerste blijkt uit de krachtige ontvouwing van de nieuwe evangelische leer, waarin de boete een centrale plaats inneemt. Het tweede blijkt uit de manier waarop hij in het kerkelijk leven in Genève vorm heeft gegeven, waarbij de tucht van de kerk een centrale rol speelt (CO 4; Inst. 3.4.23; 1559, 136). 11

In de 'Registres de la compagnie des pasteurs de Genève', die doen denken aan de middeleeuwse biechtboeken (vgl. Bergier, 1964:14-19) ${ }^{\mathbf{1 2}}$, wordt beschreven

$10 \mathrm{CO} 4$, 136. OS 4, (Inst. 3.4.23; 1559), $112=\mathrm{CO} 4,136$. Het eind van de regel 'ut tollatur publica Ecclesiae offensio' werd in 1560 kortweg 'afin que le scandal publique soit reparé'. In 1560 voegt de Franse vertaling toe: 'pour annoncer aux pecheurs que Dieu leur a fait mercy'.

11 “Car l'absolution, qui sert à la foy, n'est autre chose qu'un tesmoignage prins des promesses gratuites de l'Evangile, pour annoncer aux precheurs que Dieu leur a fait mercy. L'absolution servante à la discipline de l'Eglise, ne concerne point les pechez secrets, mais appartient à donner exemple, afin que le scandale publique."

12 CO 10a, 51-58. J.F. Bergier, Registres 1 (1546-1553). Genève 1964,14-19 = CO 10a, 51-58 (Ordonnances sur la police des eglises de la campagne). Op 16 mei 1547 werd deze regeling van kracht. Vergelijk CO 10a, 59-63 (Ordonnances sur les jurements et les blasphèmes; 1551). 
in welke richting Calvijn denkt en hoe in Genève de schuldbelijdenis en bestraffing van de zonden toeging. Op 17 december 1546 is er een adviesreglement gemaakt over allerlei zonden en de bijpassende boetedoening, bijvoorbeeld voor het bezitten van heiligenbeelden en maken van pelgrimsreizen, het vieren van paapse feesten, het bezoeken van de mis. Op dergelijke bijgelovige afgodendiensten staan gevangenisstraffen en boetes. Op Godslasteringen staat de boetestraf van het kussen van de grond bij de eerste gelegenheid, vervolgens - bij de tweede keer - een boete van vijf sous en bij de derde keer moet hij een uur vast zitten. Iemand die God of zijn doop loochent, moet negen dagen op water en brood zitten en bij een tweede en derde maal krijgt hij een strengere lichamelijke straf (punition corporelle). Wanneer iemand zich keert tegen het Woord van God moet hij verschijnen voor het consistorie of de stadsraad om bestraft te worden. Een dronkaard moet niet alleen een boete betalen, maar ook voor het consistorie verschijnen om vermaand te worden. $\mathrm{Na}$ de derde maal krijgt hij naast een geldboete een gevangenisstraf. Op het zingen van verkeerde liederen en het maken van onbehoorlijke dansen staat drie dagen gevangenschap en het gestuurd worden naar het consistorie. Verder worden woekeraars, onruststokers en ontuchtigen aangepakt. Wanneer de ontucht geen overspel is, moet de zondaar zes dagen de gevangenis in op water en brood en zestig sous betalen. Bij ontucht is de penitentie groter (Bergier, 1964:16-19). Vier jaar later verschijnt een reglement tegen het zweren en de godslasteringen. Naast vasten, geldboetes en gevangenisstraf, lezen we nu, bijvoorbeeld bij het vergelijkend artikel tegen Godslasteringen, niet alleen over een gevangenisstraf, maar ook over het op de knieën vallen en het aan God vergeving vragen. Na driemaal zo bestraft te zijn wordt de zondaar de vierde keer voor een half jaar verbannen (CO 10a, 62).13

Het gaat Calvijn om het uitbannen van de verkeerde, de zondige elementen uit de christelijke samenleving en om het veranderen van mensen, het verbeteren van hun denken en doen (changement de vie). Daarom moeten zondaren "een teken van berouw tonen". Steeds keert dit element, dat zondige mensen zich voor God moeten vernederen en tot berouw en inkeer moeten gebracht worden, terug in de kerkorde van Calvijn (Art. 158, 159 en 164 - alleen in het Frans).

In de jaren vijftig werd in Genève met het oog op het zuiver houden van de kerk, naast de afhouding van het avondmaal (excommunicatio minor), de mogelijkheid van verbanning (excommunicatio maior) opgenomen in de kerkelijke wetten. Op 12 november 1557 legde de stadsraad dit vast in een wet. De straffen bleven echter principieel getermineerd. De oude praktijk om iemand voor jaren of zelfs voor zijn hele leven een boete op te leggen, werd daarmee verworpen. Het doel van het werk van het consistorie werd hier opnieuw helder uiteengezet. Het ging erom dat door gesprek, vermaan en straf, mensen "vrijwillig" tot

Vergelijk 'Edictz et cries a cause des blaphèmes' CO 10a, 64 . 
schuldbelijdenis gebracht worden en zo aan hun herstel en dat van de kerk en samenleving kunnen werken.
Als iemand vanwege weerspannigheid of omdat hij hardnekkig blijft zondigen of omdat hij onwaardig bevonden is voor de avondmaals- gemeenschap (la saincte communion), ervan afgehouden wordt, en in plaats van zich te verootmoedigen zich aanstelt als een verachter van de kerkorde (l'ordre de l'Eglise) en als hij niet vrijwillig (de son bon gré) schuldbelij- denis komt doen in het consistorie, moet hij voor een periode van zes maanden zich van het avondmaal onthouden, en zal hij vervolgens worden ontboden en vermaand zich te onderwerpen. Volhardt hij tot het einde van het jaar zonder zich door de vermaningen aan hem gedaan te laten corrigeren, dan zal hij voor een jaar verbannen worden als een onbekeerlijk mens, tenzij dit voorkomen wordt, doordat hij om vergeving vraagt aan de raad en zijn schuld erkent in het consistorie, om zo weer te worden toegelaten tot het avondmaal (OS 2, 360).

Voor Calvijn was het avondmaal vooral een zaak van de gemeenschap en vereiste dus ook meer dan een voorbereidend zelfonderzoek. In Zürich en Bern was deze voorbereiding op het avondmaal uitsluitend geworden tot een zaak van het eigen geweten.

Calvijn was geen voorstander van verbanning. Het zou volgens hem beter zijn, zo stelt hij in de stadsraad op 30 januari 1560 , een zondaar te dwingen tot boetedoening, om "degenen aan wie de avondmaalsviering is ontzegd en die op verbanning kunnen rekenen, nadat zij zich opstandig gedragen hebben en niet zijn komen opdagen om opnieuw in de kerk ontvangen te worden, te dwingen in de kerk boete te doen (faire reparation en leglise)" (CO 10a, 120). ${ }^{14}$ Het gaat bij het verbeteren van individueel zondig gedrag door de kerkelijke ambtsdragers primair om de kerk als geheel. Dit punt verbindt Calvijn ook met de middeleeuwse biechtpraktijk.

De predikanten van Genève schrijven bijvoorbeeld aan Farel over het belang van de restitutiegedachte, die de middeleeuwse biechtpraktijk kenmerkte:

De kerk behoort van veel groter belang te zijn dan het individu. Daaruit volgt dat er geen echt en oprecht berouw (poenitentiam) bestaat, wanneer degene die is gevallen, weigert om genoegdoening te betalen (satisfacere) voor zijn overtreding.

Een openbare ergernis moet volgens Calvijn waar mogelijk worden goedgemaakt en ieder geval gecompenseerd door een of andere penitentie.

Farel, de predikant van Neuchâtel, vraagt verder om advies over mensen die zwaar gezondigd hebben. "Kan zo iemand verplicht worden op het gezag van

14 Registres du Conseil, dinsdag 30 jan. $1560=\mathrm{CO} 21,727$. 
predikanten en ouderlingen een officieel getuigenis te geven van boetedoening?" De predikanten van Genève antwoorden, dat iemand die de kerk beledigd heeft door een slechte voorbeeld en berouw heeft, "hij zijn zonde moet belijden voor de kerk (coram Ecclesiam), zodat hij zich kan verzoenen. ... Wij prijzen deze gewoonte om getuigenis van boete te geven in de aanwezigheid van de mensen (coram populo) en wij ontkennen, dat het een onbezonnen of louter menselijk verzinsel is" (vgl. Bergier, 1964) $\mathbf{1 5}$

\section{Conclusie}

Het aangehaalde 4e Lateraans concilie verklaarde drie eeuwen eerder, dat "door deze onschendbare constitutie de prelaten van de kerken op een verstandige en voorzichtige manier aandacht zullen moeten geven aan het bestraffen van hun onderdanen als zij zondigen ... en de zeden zullen moeten herstellen (reformandum mores)" 16

In allerlei opzicht spiegelde Calvijn zich aan de door de oude biechttraditie ontstane en op het vierde Lateraans concilie verbrede praktijk van biecht en boete. Terwijl in 1215 alle inwoners verplicht werden een maal per jaar te biechten bij de eigen priester, ontwierp Calvijn een huisbezoeksysteem, dat even waterdicht was, waarin iedere inwoner van Genève elk jaar aan huis verplicht een onderzoek moest ondergaan naar leer en leven door de eigen predikant en wijkouderling in de weken voorafgaand aan de Paascommunie. Daarnaast ontwierp Calvijn een plaats om te biechten voor de bijzondere gevallen, die hij plaatste tegenover het forum van tien tot twintig consistorieleden als biechtvaders. Na een aanloopperiode functioneerde het Geneefse consistorie zeer effectief als "biechtstoel". Gemiddeld tien mensen per week werden in de jaren vijftig in Genève gedagvaard om voor het consistorie boete te doen. Evenals in de middeleeuwse wetgeving werd de omgang met onboetvaardigen strikt verboden met een beroep op Paulus (OS 2, 363; Tanner, 1990 1:234 [canon 3]).

Met de reformatoren had Calvijn zich uitgesproken voor de vrijheid van het schuldbelijden aan elkaar, hoewel in het bijzonder aan de predikant, en tegelijk in afwijking van reformatoren als Luther, Zwingli en Bullinger - was hij voor de verplichting van een jaarlijks geloofsonderzoek aan huis en waar nodig onder dwang voor het consistorie.

In de stadsraad van Genève drukte Calvijn zich eind november 1561 zelfbewust uit over de resultaten van zijn opzet. Voor hem was de Geneefse boetepraktijk

Registeres 1, 142929 juli $1552=$ CO 14, 345-347.

16 Mansi, vol.22, 991-994 = Tanner, Decrees 1,237 (canon 7: De correctione excessuum). Het concilie merkt hierbij op, met een verwijzing naar Ezechiël 3, dat als de ambtsdragers in gebreken blijven het bloed van hun hand geëist zal worden. Calvijn doet eenzelfde beroep op Ezechiël 3. Vgl. Speelman (1997:182, n. 31). 
een voorbeeld voor alle kerken, zowel voor die met de reformatie zijn meegegaan, als die daarbuiten ${ }^{17}$ (vgl. Speelman, 1994:187, aant. 1).

\section{Literatuurlijst $\mathbf{1 8}^{\mathbf{1 8}}$}

BERGIER J.F. 1964. Registres de la Compagnie des pasteurs de Genève au temps de Calvin. Publiés sous la direction des Archives d'Etat de Genèves par R.M. Kingdon et J.F. Bergier. Tome premier: 1546-1553. [Travaux d'Humanisme et Renaissance, 55]. Genève.

BOYLE L.E. 1974. The Summa for confessors as a genre, and its religious intent. (In Trinkaus, C. \& Oberman, H.A. The pursuit of holiness in late medieval and Renaissance religion. Papers from the University of Michigan Conference. Leiden. p. 126-130.)

BUSCH, E. \& OPITZ, P. e.a.. 1996. Calvin Studienausgabe. Gestalt und Ordnung der Kirche. Vol. 2. Neukirchen.

CALVIJN, J. Joannis Calvini Opera Selecta 1926-1900. Ed. Barth, P. \& Niesel., G. 5 vol.. Monachii. [= OS].

CALVIJN, J. Ioannis Calvini Opera quae supersunt omnia 1863-1900. Ed. Baum, G., Cunitz, E. \& Reuss, E. 59 vol. Brunsvigae. [CO].

DENZINGER, H. 1937. Enchiridion Symbolorum. Definitionum et declarationum de rebus fidei et morum. Ed. 21-23. Friburgi.

DIETTERLE, J. 1903. Die Summae confessorum (sive de casibus conscientiae). Zeitschrift für Kirchengeschichte [=ZKG], 24:374.

ERASTUS, Th. Explicatio gravissimae quaestionis utrum Excommunicatio, quatenus, Religionem intelligentes et amplexantes, a Sacramentorum usu propter admissum facinus arcet; mandato nitatur Divino an excogitata sit ab hominibus Th. Erastus, Pesclavii 1589.

GERSON, J. Tractatus de arte audiendi confessiones, De Pin 2,446B-453A.

HARNACK, A. 1892. Medizinisches aus der ältesten Kirchengeschichte. Texte und Untersuchungen zur Geschichte der altchristlichen Literatur. Red. Von Gebhardt, O. \& Harnack, A. Vol. 8, no. 4. Leipzig. p. 37-147.

HERMINJARD, A.-L. 1866-1897. Correspondance des Réformateurs dans les pays de langue française. 9 vol. Genève et Paris. [= Hermj.]

KINGDON, R.M. 1962. Registres de la Compagnie des Pasteurs de Genève au temps de Calvin. Genève.

LEA, H.C. 1968. Auricular confession and indulgence in the Latin Church 1. New York.

MANSI, J.D. 1961. Sacrorum conciliorum nova et amplissima collectio. Vol. 22. Graz.

McNEILL, J.T. 1932. Medicine for sin as prescribed in the penitentials. Church History, 1:1426.

McNEILL, J.T. 1951. A history of the cure of souls. New York.

NIESEL, W. 1938. Bekenntnisschriften und Kirchenordnungen der nach Gottes Wort reformierten Kirche. 3e ed. Zürich.

OHST, M.1995. Pflichtbeichte. Untersuchungen zum Busswesen im Hohen und Späten Mittelalter. Tübingen.

SCHMITZ, H.J. 1958. Die Bussbücher und das kanonische Bussverfahren. Nach handschriftlichen Quellen dargestellt II. Graz.

SPEELMAN, H.A. 1994. Calvijn en de zelfstandigheid van de kerk. Kampen.

17 CO 10a, $92=\mathrm{CO} 21,766$.

18 Bibliografiese gegewens soos deur die outeur verskaf. Uitgewers van publikasies is nie vermeld nie - Red. 
SPEELMAN, H.A. 1997. De zin van het ambt in de kerk. (In Brinkman, M.E. \& Houtepen, A. Geen kerk zonder bisschop? Over de plaats van het ambt in de orde van de kerk. Utrecht.)

STRIJARDS, H. \& SPEELMAN, W.M. 1998. Omkeren op de ingeslagen weg. Een heroverweging van het pastoraat van schuld en verzoening. Jaarboek voor Liturgieonderzoek.

TANNER, N.P. ed. 1990. Decrees of the Ecumenical Councils 1. London.

TENTLER, T.N. 1977. Sin and confession on the eve of the Reformation. Princeton. 